University of Nebraska - Lincoln

DigitalCommons@University of Nebraska - Lincoln

Textile Society of America Symposium

Proceedings

Textile Society of America

2020

Enigmatic Mediterranean Silk Quilts

Kathryn Berenson

Follow this and additional works at: https://digitalcommons.unl.edu/tsaconf

Part of the Art and Materials Conservation Commons, Art Practice Commons, Fashion Design Commons, Fiber, Textile, and Weaving Arts Commons, Fine Arts Commons, and the Museum Studies Commons

This Article is brought to you for free and open access by the Textile Society of America at DigitalCommons@University of Nebraska - Lincoln. It has been accepted for inclusion in Textile Society of America Symposium Proceedings by an authorized administrator of DigitalCommons@University of Nebraska - Lincoln. 
Published in Hidden Stories/Human Lives: Proceedings of the Textile Society of America 17th Biennial Symposium, October 15-17, 2020. https://digitalcommons.unl.edu/tsaconf/ Copyright $\odot 2020$ Kathryn Berenson doi: $10.32873 /$ unl.dc.tsasp.0073

\section{Enigmatic Mediterranean Silk Quilts}

Kathryn Berenson

kwberenson@gmail.com

In July 1886, the 1st Earl of Wharncliff offered a large, elaborately quilted silk bed cover to the Victoria and Albert Museum (V\&A), London. Never before had museum staff seen a quilt like this and their initial description hints at controlled excitement: "Near the bottom are two pairs of female figures under arcades and confronting one another. Above these are a seated figure playing the fiddle, and, on either side, a mounted Knight with drawn sword"; it goes on to note warriors, a crowned two-headed eagle and beasts facing each other (Illustration 1). ${ }^{1}$ This, the first recorded museum acquisition of an "enigmatic" quilt, is indigo blue silk on one side, a much-faded red silk on the reverse. Curators grappled with attribution. "German?" is scribbled on the intake record although two years later a curator saw an "Oriental influence," determined that quilt motifs matched those in an Indian embroidery and changed the attribution to IndoPortuguese or Indo-Dutch. Current catalog notes credit "Spain or Italy," made 1600-1699.

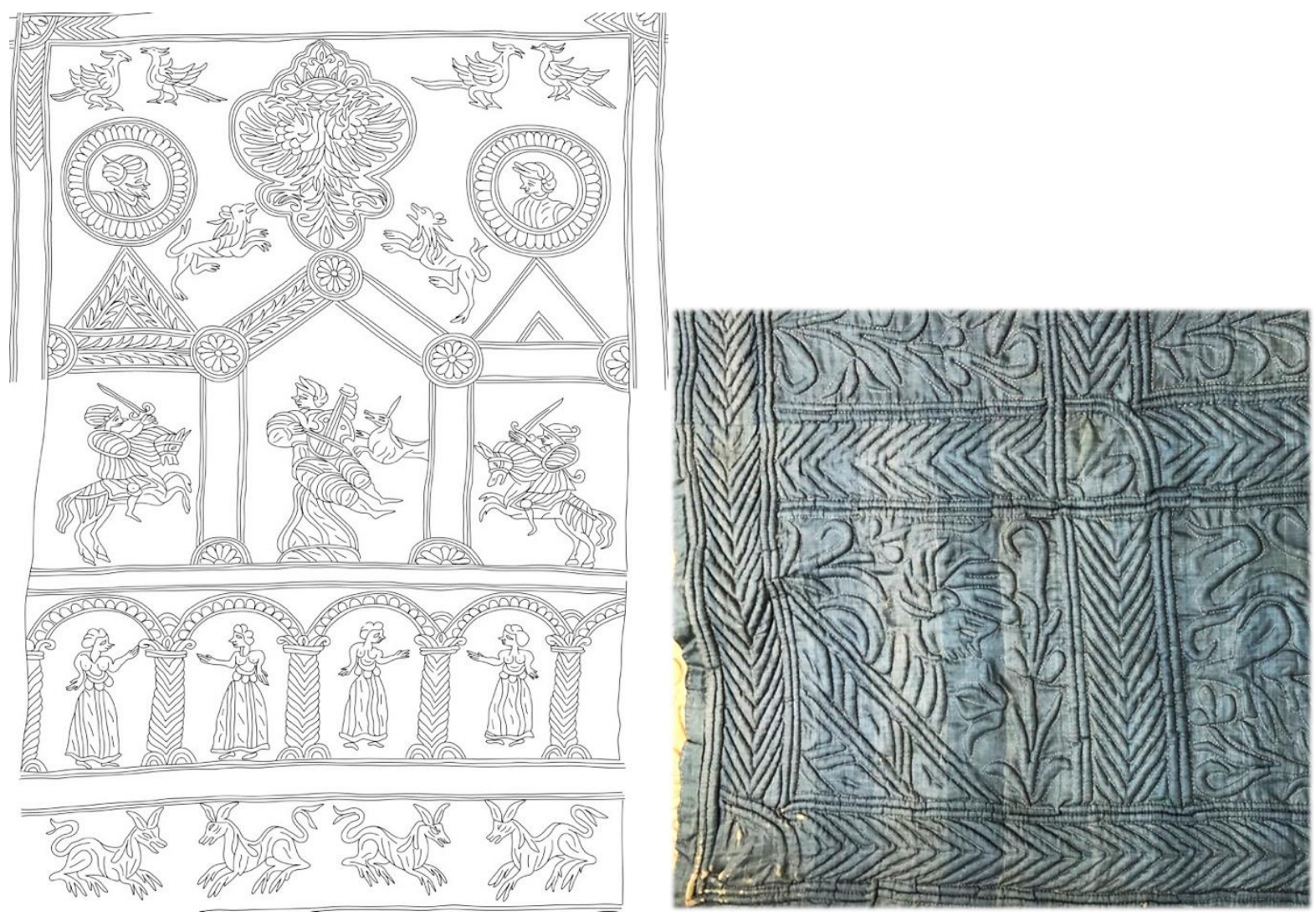

Illustration 1: At left, a drawing of the inner panel of V\&A Bed Cover 349-1886 with a crowned double-headed eagle flanked by portrait roundels, the musician, mounted knights and a gallery of semi-nude female figures. At right, the front left corner of the shows a man in a turban. Drawing (C) Linda Baumgarten, photo by author. Courtesy of Victoria \& Albert Museum, London.

${ }^{1}$ Bed Cover 349-1886, V\&A Museum Archives Register No. 100, Science \& Art Dept. 77-350; MA/30/134, not paginated. For more images and catalogue information about the quilts in this paper, see links to museum websites in Appendix 1. 
Since then, 20 similar silk quilts have entered European and North American collections. Their imagery of authority and diversion is stitched into richly colored silks: golden yellow, ruby red, blue, coral, emerald green. Medallions honor kings and sultans, galleons battle at sea, hunters stalk their prey. An Orpheus figure tames beasts with his playing and half-dressed women pose in arcades. Intricate arabesque forms lead the eye from one figure to the next such that these quilts seem to blend the arts of Europe and the Islamic world. Despite, and perhaps because of this mélange of cultures, no one yet has determined exactly where and when they were made and that's the enigma. To seek a solution to this puzzle, this paper reviews materials and techniques used to make these enigmatic furnishings, research to date, the hands they passed through before entering collections, early quilt sources, motif symbolism and a brief history of international affairs dating 1550-1720. Considered together, these small studies point to the possibility that workshops produced these quilts much later, when three world powers resolved a centuries-long conflict.

Materials and Technique: All quilts in this group are made with similar materials and technique. Assembled lengths of silk panels form front and back, one color on one side, a different color on the reverse. The silks are thin and plain-woven, with 33-34-inch selvage widths, reduced to 3032 inches when quilted. ${ }^{2}$ Needleworkers used a technique akin to corded and stuffed-work quilting, in which multi-ply cording or loose cotton is inserted through small holes on one side to raise surface patterns. The bold raised surfaces that distinguish the enigmatic silk quilts come from rolls of cotton wool, a rotund one-fourth to three-eighths of an inch in diameter.

Apparently, the rolls were settled in as the quilting lines were stitched; no small holes are visible on front or back. Quilters worked in running stitches, using silk thread. Although other quilts were made of similar plain-woven silks, the use of these firm rolls of cotton, together with ship, musician and other figurative motifs, set this group of quilts apart from all others (Illustration 2).

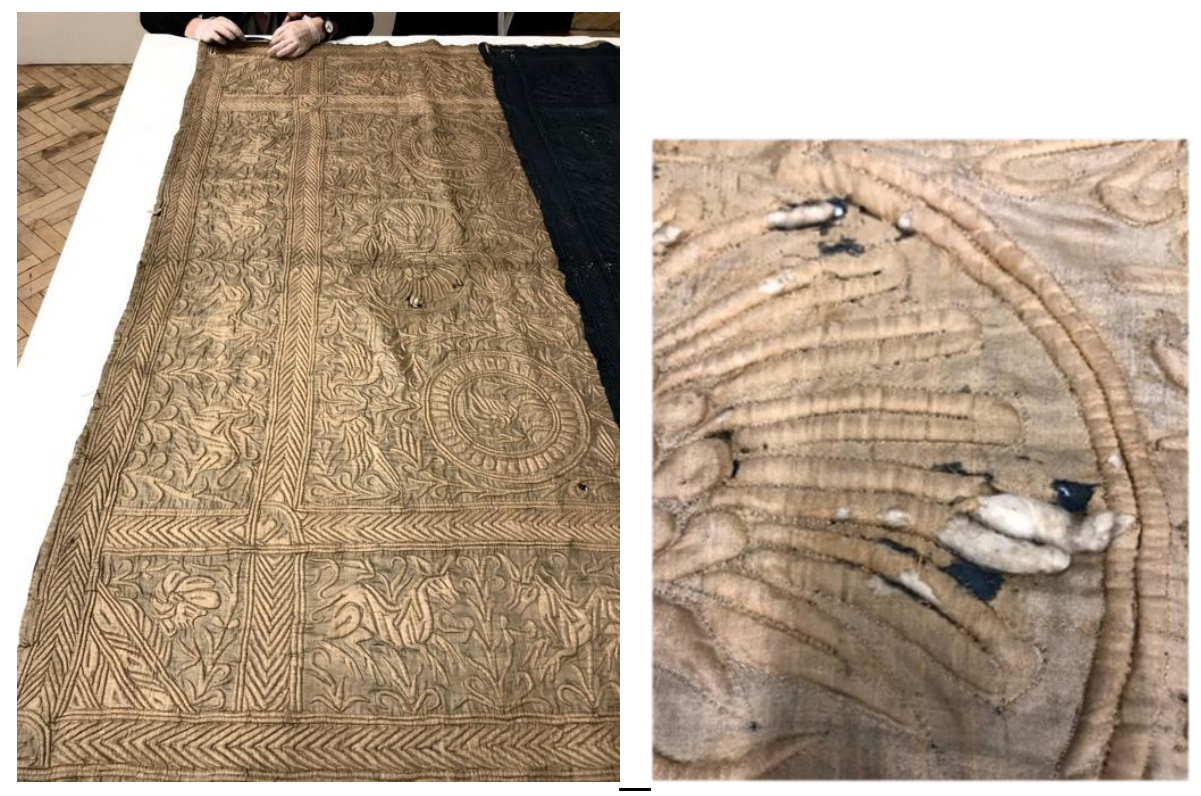

Illustration 2: V\&A Bed Cover 349-1886: At left, the large scale of the complex designs is apparent. At right, twists of cotton emerge from the worn, faded red reverse side of the quilt. Photos by author. Courtesy of Victoria \& Albert Museum, London.

\footnotetext{
${ }^{2}$ The Art Institute of Chicago quilt 1960.889, made of silk satin only 20 inches wide, may be a later copy.
} 


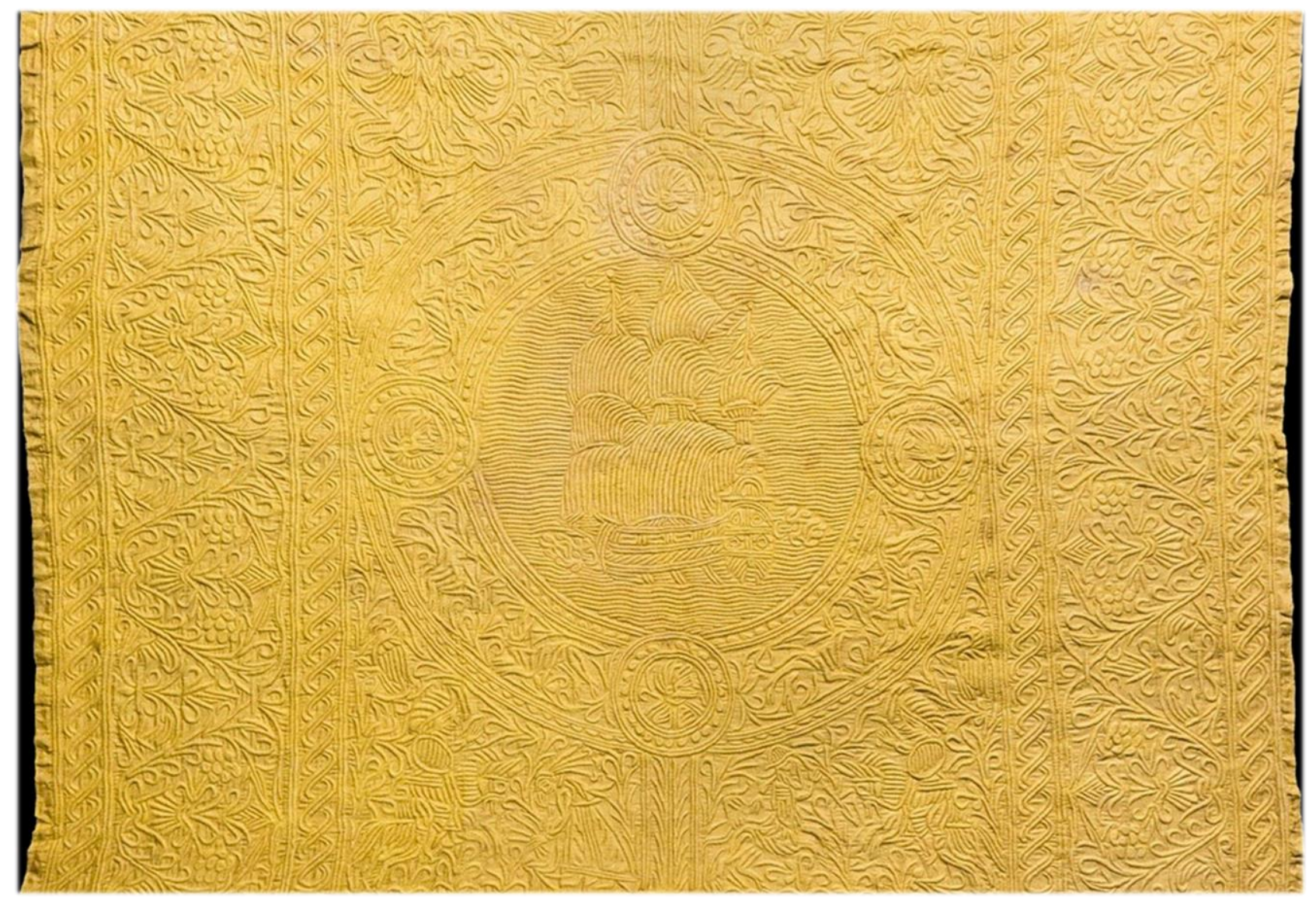

Illustration 3: Center Medallion, Quilt 1954.0049. (C) 2009 Winterthur Museum, Garden \& Library. The 1954 invoice from New York dealer Elinor Merrell to museum founder Henry Francis du Pont reads, "Yellow silk quilted spread, ship in center."

Research to Date: No one knew much about these intriguing quilts until Margaret Renner Lidz published an article based on a piece the Winterthur Museum acquired in 1954 (Illustration 3). ${ }^{3}$ She compared its motifs, materials and attribution to others known to be in US and international collections, many of them said to have been made in Portugal or in India for the Portuguese market. Lidz consulted V\&A Indian textile specialist Rosemary Crill and Teresa Pacheco Periere, textile curator at the Museu Nacional de Arte Antiga, Lisbon, who refuted those attributions, each stating there was no evidence of production of these singular quilts in their country of specialty. ${ }^{4}$ Lidz presents a compelling tentative case that the "mystery quilts," as she calls them, could have been made on the island of Chios (then in the Ottoman Empire). She quotes longtime island resident Gaspar Campion, who wrote in 1569: "We [the English] do use to buy many of their silke quilts ... that the poor people make in this town more than any other nation." However, within her article, Lidz acknowledges that "quilt" is often used in reference to Indian layered coverlets that have no inner filling, which weakens the usefulness of the Campion reference. ${ }^{6}$ Nevertheless, Anna Ballian uses that same Campion citation to support her

\footnotetext{
${ }^{3}$ Lidz, "Mystery of Seventeenth-Century Quilts," 834-843.

${ }^{4} \mathrm{Lidz}, 836$.

${ }^{5}$ Lidz, 840-842; 843 n21; see Argenti, The Occupation of Chios, 492.

${ }^{6} \mathrm{Lidz}$, "Mystery of Seventeenth-Century Quilts," 838, 840. Lidz, 88, also learned that the silk widths of silks from Chios did not exceed 27 inches, thus were narrower than silk panels in the study quilts.
} 
theory that needleworkers on Chios made two quilts now in Greek collections made of plain colored silk on the front, another textile on back (perhaps of linen, not silk), quilted in what appears to be the corded technique, parallels of the enigmatic quilts although with fewer motifs and no scenes of ships or human figures. ${ }^{7}$ Ballian's citation of the Campion reference to "silke quilts" has its own problem: "silke" could refer to quilts made of the patterned and figured Chian silk weaves that Ballian discusses at length in the same article. This single quotation from 1569, unsupported by other data, does not seal the case for Chios production of the two quilts Ballian writes about. ${ }^{8}$ They may have been imports; as Amanda Phillips writes, "Chios was as much a locus of transshipment as of production.",9

In 2005 the Colonial Williamsburg Foundation (CWF) acquired an enigmatic quilt, prompting textile curator Linda Baumgarten, to again examine similar quilts in other museums. ${ }^{10} \mathrm{She}$ measured textiles, counted stitches, reviewed accession files, and studied motifs in detail through the use of computer assisted design technology (see her drawings in this paper). ${ }^{11}$ Baumgarten is the first to publicly suggest the musician depicted in eight of the quilts represents Orpheus, the son of a Greek god whose musical talents could calm tempests and tame the wild beast, and she also links numerous quilt motifs to those found in sixteenth-century engravings and maps, hunting scene costumes to late fifteenth-century European dress, and ship motifs to galleons that date between 1550 to the early 1600s. Baumgarten concludes that these quilts likely were made circa 1600 in Mediterranean or Aegean Sea area workshops. ${ }^{12}$

Analyses of the dyes used to color the silk supports those geographic limits. Two institutions found the dyes within them correspond only to those in European, Turkish and Persian textiles. ${ }^{13}$ Previous research of these colleagues makes it increasingly probable that the enigmatic quilts, made of silks dyed with European color agents, were produced in southern Europe or near Mediterranean and Aegean ports that had access to those dyes, with the exclusion of Portugal and India and possible exclusion of Chios.

Tracing Ownership: Quilts in this study are now in British, French, US and Canadian collections; none yet are reported elsewhere. ${ }^{14}$ The little provenance available links them to Britain, France, Italy and Unknown. Museum records name donors, dealers and auction houses, but that's about

\footnotetext{
${ }^{7}$ Ballian, "From Genoa to Constantinople: The Silk Industry of Chios," 92-98. Ballian refers to Benaki Museum quilt inv\# 93 and a quilt in a private collection. Sumiyo Okumura also discusses the Benaki piece in "Hidden Story of the 'Mamluk' Quilt Cover in the Collection of the Benaki Museum," within these same TSA 2020 Symposium Proceedings, not published as of this writing.

${ }^{8}$ Lidz, "Mystery of Seventeenth Century Quilts," 841.

${ }^{9}$ Phillips, Everyday Luxuries, 94.

${ }^{10}$ CWF Silk Quilt inv. 2005.94.

${ }^{11}$ See more Linda Baumgarten drawings at http://www.lindabaumgarten.com/Research.html, scroll to "Online Publications," click on "The Designs on a Group of Reversible Silk Quilts."

12 http://www.lindabaumgarten.com/Research.html, scroll to "Online Publications," click on "The Mystery of Silk Cord Quilts," April 2009 meeting of American Quilt Study Group; Baumgarten and Ivey, Four Centuries of Quilts, 21-28.

${ }^{13}$ Eaton, Quilts in a Material World, 112-114. Analysis by the Koninklijk Instituut Voor Het Kunstpatrimonium, Belgium in 1999. The Textile Research in Archaeology laboratory, York, Britain, reported their dye test results 30 June 2000; Titi Halle, email message to Linda Baumgarten, September 11, 2012.

${ }^{14}$ Abegg-Stiftung has none, despite being a major repository of historic textiles. Anna Jolly, curator, email message to author, September 23, 2019.
} 
it. However, from the end of the nineteenth century those textile dealers and their clients wellrecognized the appeal of these double-faced silk quilts. Wealthy patrons donated silk quilts from their own collections to the Art Institute of Chicago, Boston's Museum of Fine Arts, the Isabella Stewart Gardner Museum (Gardner bought it from an Italian dealer in 1897) and the Winterthur Museum (bought from a New York dealer). The Wadsworth Atheneum Museum of Art acquired its quilt from museum consultant and dealer Cora Ginsburg; V\&A archival records show that in 1967 Italian architect Sandro Angelini, of Bergamo had owned it. ${ }^{15}$ The quilt now in the Musée des arts décoratifs de l'Océan Indien (MAD) in Réunion, a French territory, first surfaced at an antique show in Florence, Italy. ${ }^{16}$ Often quilts pass through many hands before landing in a collection. An extreme example of this applies to a silk quilt that traces to dealers in Provence (who also first offered Colonial Williamsburg's quilt), then bounces through three other dealers and two auction houses before reaching the National Maritime Museum in Greenwich, UK. ${ }^{17}$ Alas, knowing that three enigmatic quilts came from Italy and two from Provence does not identify their true origins.

Five families linked to homes near SW England seaports offered their quilted heirlooms directly to museums. Betty Kingston donated an emerald green silk quilt to the Royal Ontario Museum, Toronto, in 1975 (Illustration 4). Kingston said that her great-grandmother brought the quilt to Canada from their home "Tonnacombe," in Cornwall. The same family line that built the sixteenth-century Tonacombe Manor still occupies it. Past manor kin held high positions in Asian trade, the British navy, the Church, and tin mining; some, like the donor's greatgrandmother, emigrated to North America. ${ }^{18}$ In 1937, the Reverend G.W. Saunders of Martock, east of Cornwall, offered a worn green silk quilt to the V\&A, saying he knew only it had been in his wife's family for "a very long time." ${ }^{19}$ In 1953 the V\&A accepted a silk quilt from the collection of a resident of SW Britain resident who died in $1901 .^{20}$ A gold silk quilt surfaced in Truro, Cornwall, during a 1993 survey of British quilts. ${ }^{21}$ The owner's mother had received it about 60 years earlier from Lady Seaton, wife of the 3rd Lord Seaton, a descendant of Sir Francis Drake. The Seatons lived in Buckland Abbey, near Plymouth, the home Sir Drake bought in $1581 .^{22}$ As it turns out, Lord Wharncliff, who offered the indigo silk quilt to the V\&A,

${ }^{15}$ V\&A Archives MA/1/B1047. In 1967, Santina Levey, then at the V\&A, compared a potential purchase to photos of Angelini's quilt. Lidz attempted to consult a photo of it but V\&A curators could not locate any. Today, the Wadsworth has an old print of the quilt that matches Levey's description of Angelini's piece.

${ }^{16}$ Titi Halle, email message to author, September 9, 2019.

${ }^{17}$ Nicole Fabre, interview by author, October 15, 2019. Fabre, a London dealer, bought the quilt from the Provencal dealers, then sold it to Ginsburg, who consigned it to Christie's, an unknown buyer bought it and turned it around to Sotheby's, where NMM acquired it. Titi Halle, email message to Linda Baumgarten September 11, 2012.

${ }^{18}$ https:/opc-cornwall.org/Records/parishes/L-P/pdfs/morwenstow_mis.pdf; genesreunited.co.uk/boards /board/ancestors/thread/408287. About 6,000 emigrants from Cornwall and Devon departed for Canada from Padstow (40 miles from Tonacombe Manor) between 1831-1860; see Payton, "Maritime history and the emigration trade," non-paginated.

${ }^{19}$ V\&A T.62-1937; Archive file RF 914/1937. G.W. Saunders, letter to Keeper of the Department of Textiles, V\&A Museum, January 15, 1937.

${ }^{20}$ V\&A T.207-1953; Archive file MA/1/S3475. Charles Stilwell, letter to V\&A Museum, March 30, 1953.

${ }^{21}$ Heather Audin, curator, The Quilters' Guild of the British Isles, email message to author, September 15, 2020. I thank Bridget Long, for sending me notes from her examination of the quilt on May 22, 1993.

${ }^{22}$ historicengland.org.uk/listing/the-list/list-entry/1018366 

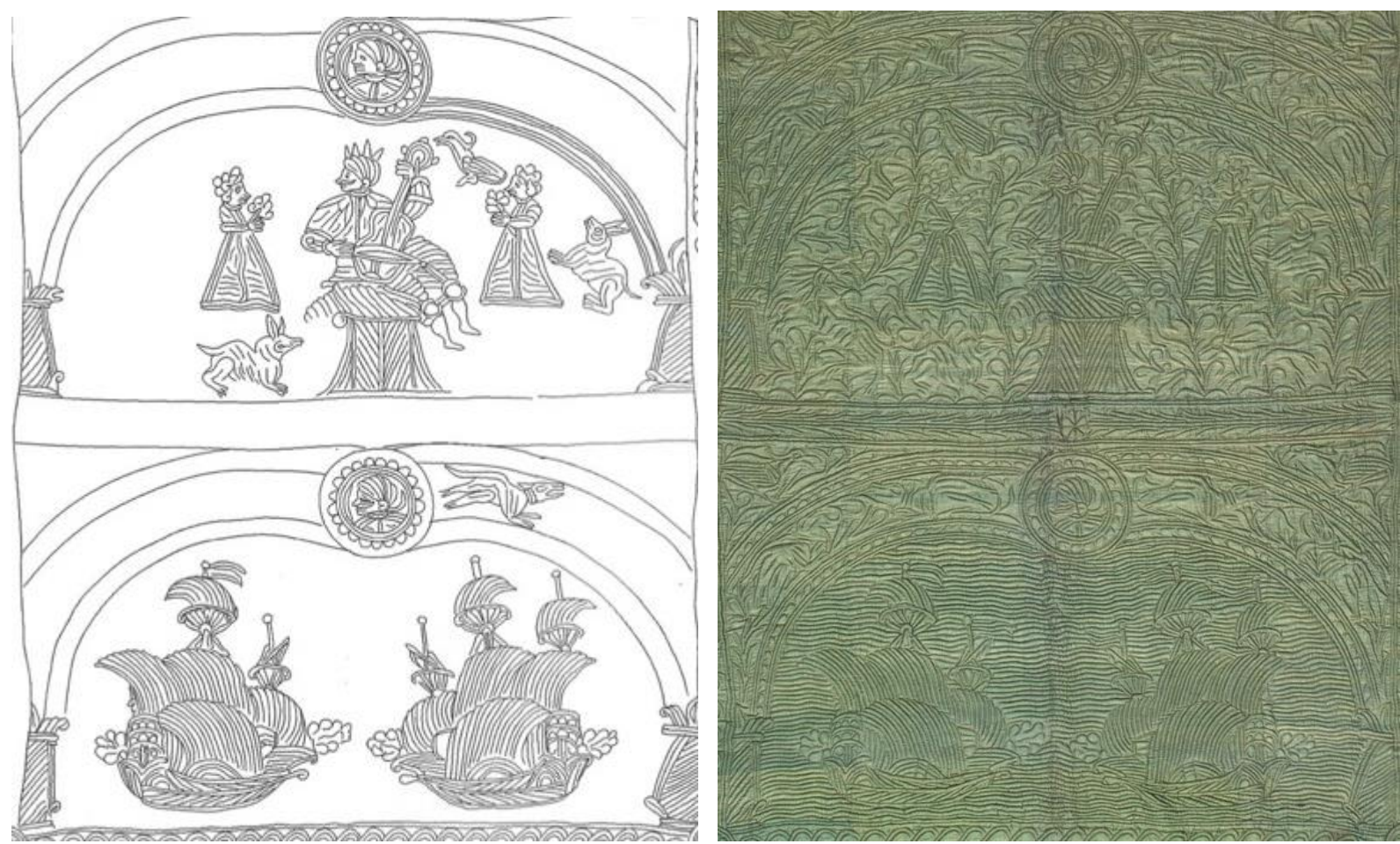

Illustration 4: Inner panel layout of Royal Ontario Museum 975.349, Gift of Betty Kingston. Drawing @ Linda Baumgarten.

also had a Cornwall estate, near Tintagel. At his death, his tenants installed a stained-glass window in their local church in "affectionate memory" of the earl. ${ }^{23}$

But why would so many families in SW Britain have these exotic furnishings? The region is a spit of land extending into the Atlantic Ocean; for centuries its economic base centered on its harbors -- and exports of its tin. Tin is a necessary element of bronze and pewter and Cornwall had the world's largest supply. From around 440 BCE through the 1700s, Cornish mines supplied tin, to huge profit, to most of Europe and the Mediterranean basin. ${ }^{24}$ Tax income from tin induced the crown to establish the Duchy of Cornwall in 1337, whereby the duke received the proceeds. In his 1714 Account of the Duchy, Sir John Doddridge writes, "In the south west of Britain there is found great quantities of Tin, the purest, best and most plentifullest in Europe; by reason whereof, it hath ever been accounted one of the staple commodities of this kingdom, and of good estimation in foreign parts." 25 The income from tin mining, processing and international sales could support a wealthy upper class and Cornish tin merchants were known to at times send their own shiploads of tin, legally and covertly, to Ottoman ports on the Mediterranean. ${ }^{26}$ Upon their return, ships were laden with commodities and luxuries, seen in Cornish inventories. ${ }^{27}$

${ }^{23} \mathrm{https}$ //www.cornishstainedglass.org.uk/mgsdb/window.xhtml?churchid=272\&locid=61

${ }^{24}$ Gerrard, The Early British Tin Industry, 20. Gerrard quotes Diodorus Siculus (8 BCE), "The natives of Britain by the headland of Belerium are unusually hospitable, and thanks to their intercourse with foreign traders have grown gentle in their manner."

${ }^{25}$ Whetter, Cornwall in the Seventeenth Century, 59, $80 \mathrm{n} 1$.

${ }^{26}$ Doe, "Cornish Ports in the Eighteenth Century," in Payton, et, al., Maritime History of Cornwall, 183.

${ }^{27}$ See http://www.nationaltrustcollections.org.uk/ 
Early Quilt Sources: Quilted furnishings with figural motifs appear in inventories throughout Europe from the fourteenth through the seventeenth centuries. ${ }^{28}$ Most listings rarely identify textiles or motifs, much less origins. However, 13 island of Sicily testaments and dowries dated between 1393 and 1508 describe costly quilted bedcovers exported from the port of Tripoli. ${ }^{29}$ One notary even wrote the quilt was "made, as is commonly said, in the port of Tripoli [author's italics]." "30 Syrian Tripoli, a major international shipping port, had quantities of domestic woven lightweight silk and cotton wool, precisely the materials that make up enigmatic quilts. ${ }^{31}$

Island of Sicily notaries also named the city of Naples as the source of figured quilts. A wealthy Palermo merchant's son inherited a large bed quilt napolitanam laboratam ad figuras, or "from Naples, worked with figures"; three listings describe quilts "made in Neapolitan style," one of them showing hunting scenes. ${ }^{32}$ The 1393 inventory of Pierre, count of Geneva, names sources and textiles of many quilts: one in black silk with viper and lily motifs, one in red and black silk depicts the story of Solomon, and two others of unknown textiles filled with figures, all of these from Naples. ${ }^{33}$ The count also bought three quilts in the mainland Kingdom of Sicily, one with bird motifs and magnis undis, Latin for "large waves." 34 Max Bruchet wrote that the many references he sees to quilts with ondes and undas must be in response to the quilts' wave-like surfaces, an observation that applies equally well to the surfaces of those in this study. ${ }^{35}$ French notaries recognized characteristics of Italian quilting around 1510: two quilted furnishing descriptions read "in the style of Italy"; a third inventory states a quilt is the "work of Italy." "36

Early English, French, Italian and Spanish inventories through the later 1600s record hundreds of two-color quilts, most of them yellow/red, but also yellow/blue and blue/red, the same color combinations of the enigmatic quilts, albeit these may be made of two-color weaves, or represent quilts with a contrasting border. ${ }^{37}$ European guilds and workshops produced silk quilts, but when notaries give details, these are embroidered, hold applied heraldic devises, or are colorful weaves. No other inventories, out of hundreds dating 1400-1800, specify locations identified with production of figurative, high relief quilted furnishings fashioned from the lightweight plain-weave textiles that make up the enigmatic group, leaving Tripoli and sites on the Italian peninsula as good possibilities for their origin.

${ }^{28}$ See detailed discussion of early quilts in Berenson, "Italian Bedfellows." Although island inventories list hundreds of quilts, the many claims of island of Sicily quilt production, including of the Tristan Quilts, are not supported by documentation and were likely imported. The first mention of an island of Sicily quilt workshop dates to 1507; Mauceri, "Inventori inediti," 105

${ }^{29}$ Bresc-Butler and Bresc, Une maison de mots, I, 78; II, 585; IV, 1164; V, 1317, 1413, 1502, 1532, 1562 , 1575; and Mauceri, "Inventari inediti," $107 \mathrm{n} 1,111$.

${ }^{30}$ Bresc-Butler and Bresc, Une maison de mots, III, 801.

${ }^{31}$ Gay and Stein, Glossaire Archéologique, 295, 296, 297; and Mazzaoui, The Italian Cotton Industry, 34 n37. The city of Tripoli is now in Lebanon.

32 Bresc-Butler and Bresc, Maison de mots: Inventaires, I, 78; IV, 983; V, 1137; 1445, 1548.

${ }^{33}$ Bruchet, "Trois inventaires," 339-340. Several quilts "of Naples" went to Pierre's niece, Elipde de Baux.

${ }^{34}$ Bruchet, 340, 359.

${ }^{35}$ Bruchet, $340 \mathrm{n} 1$. Bresc-Butler and Bresc, Maison de mots, I, 78: the authors count 85 out of 875 total quilts described as having undas. The 1382 testament of Charles V of France notes five quilts stitched in "waves," see Labarte, Inventaire de Charles V, 248, 344, 392. gallica.bnf.fr/ark:/12148/bpt6k114570g.

${ }^{36}$ Havard, Dictionnaire de l'ameublement, I, 249; Deville, Comptes de dépenses, 488.

${ }^{37}$ For example, in 1523, Henry VIII seized a red/yellow silk quilt owned by Lady Agnes Hungerford, “attainted of murder"; www.british-history.ac.uk/letters-papers-hen8/vol3/pp1188-1205\#highlight-first, \#2861. 
Significance of the Motifs: The patron or designer of the figurative quilts chose the subjects - the hunt, galleries of women, Orpheus, ships and heraldic emblems - purposely, to convey recognizable meaning. The five quilts in this study that are filled with the curved rhythmic patterns called "arabesque" exemplify European embrace of Islamic decorative arts. In the 1500s Italians engraved dozens of arabesque forms for embroiderers to copy. ${ }^{38}$

Hunt imagery appears in Islamic and Western arts throughout the centuries as a metaphor for virility and as validation of the right to rule. (Ottoman hunting images put paid to the common belief that the human figure was totally forbidden in Islamic art.) Nearly all enigmatic quilt borders hold scenes of luxurious foliage where hunters pursue their prey. The quilt illustrated below shows Europeans and Ottomans hunting, then relaxing after the hunt, altogether in harmony. It can be difficult to discern differences in dress between the two cultures as both have clothing that fits close to the body: tapered jackets, short pants and high boots (Illustration 5).
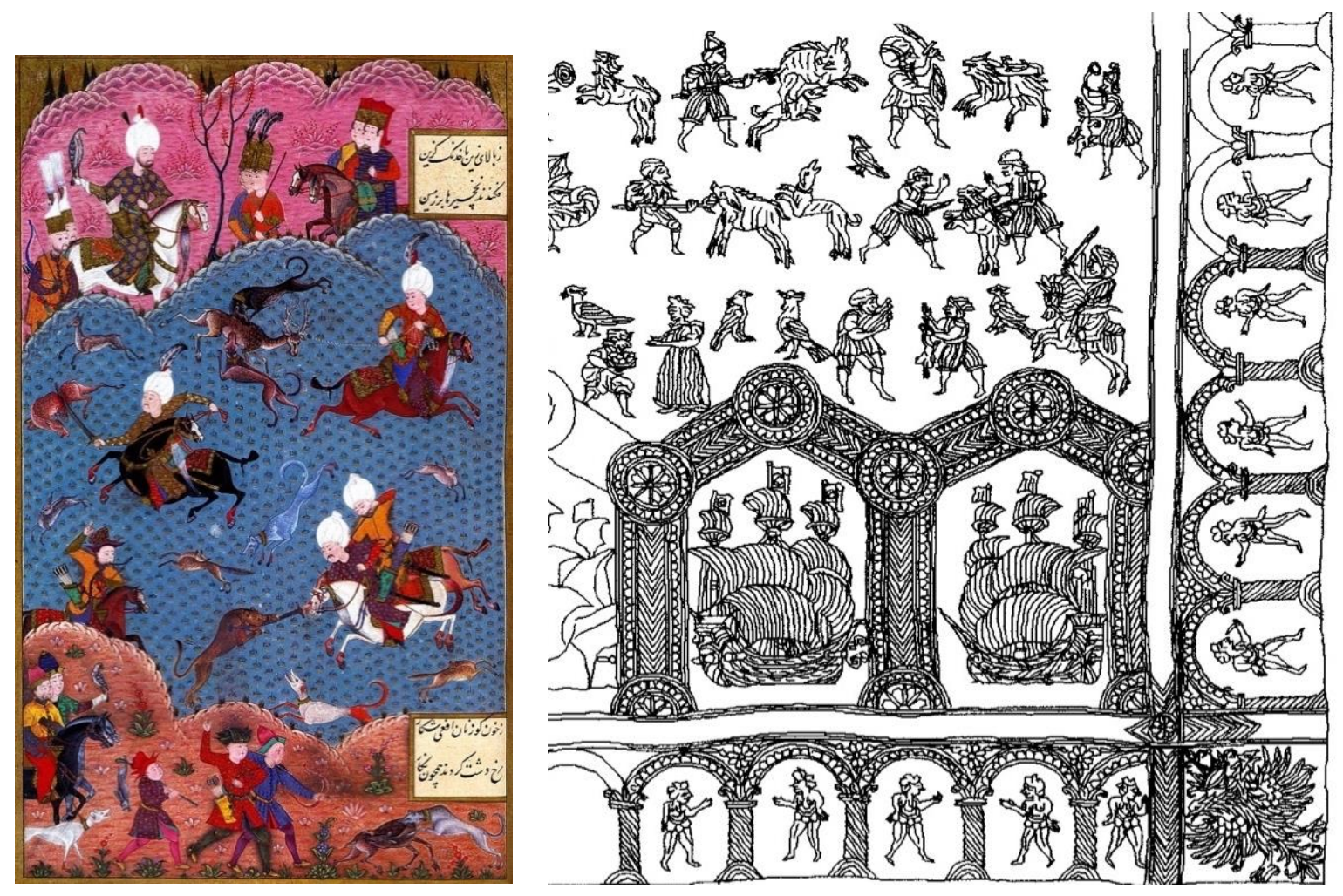

Illustration 5: At left, Mounted Ottomans pursue deer and a lioness in "Süleyman hunting with Selim" Aleppo, 1553; Topkapi Saray Museum, Istanbul ms Hazine 1517 folio 576a. At right, at the top, a hunter in European garb spears a boar while next to him the Ottoman man wearing a turban readies to strike a lion; lower section of Musée des arts décoratifs de l'Océan Indien, Réunion quilt 996-1022. Drawing (C Linda Baumgarten.

The skimpily dressed female figures adjacent to heraldry, ships and hunting parties in the quilt drawing above are an anomaly - why and where did the designer come up with these images? In the early 1600s semi-nude women rarely appeared in Ottoman art, when they did it was for domestic clients only. By the 1660s Europeans could buy whole costume albums and William Kynan-Wilson writes "they did contain depictions of barely clothed Oriental women [Kynan-

\footnotetext{
${ }^{38}$ Giovanni Antonio Tagliente and Alessandro de Paganini published arabesque designs in the 1530s.
} 
Wilson's italics]." ${ }^{39}$ But even in these Turkish costume albums, artists portrayed their subjects in private settings where the viewer would not be welcome. The women depicted in three study group quilts strike poses that invite viewer admiration, comparable to engravings, posters and even card games produced by European artists at a much later period than previous studies have assigned to the enigmatic group (Illustration 6). As to why any partially nude figures were represented in the quilts -- that is an enigma in itself. They certainly are not Ottoman renderings.
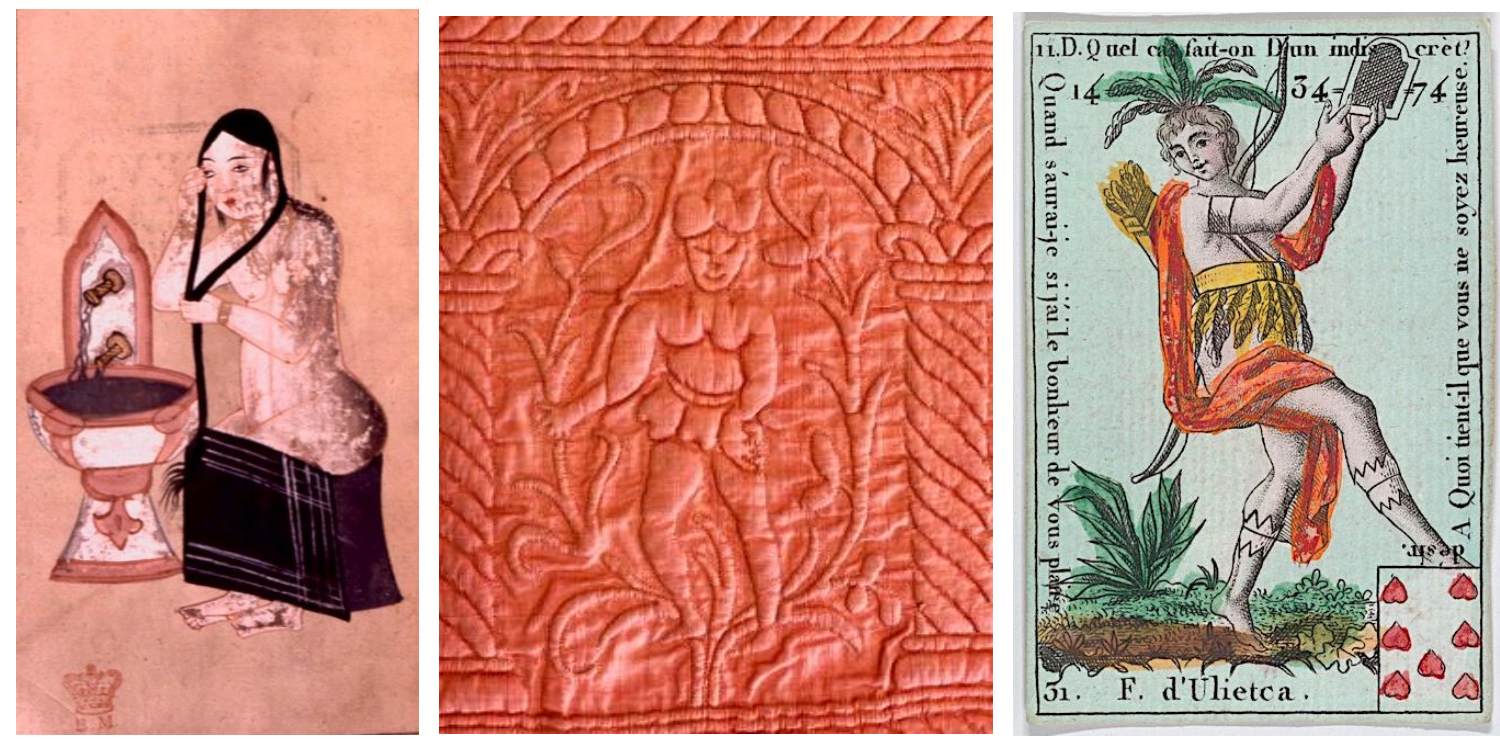

Illustration 6: At left, “Woman bathing in Hammam," The Habits of the Grand Signor's Court, 1620, Ottoman School, Turkey; British Museum, 1928,0323,0.46.121, @ The Trustees of the British Museum; In center, detail of a female figure who wears only a skirt of leaves, National Maritime Museum bedcover ZBA4285, (C) Cora Ginsburg LLC; at right, a playing card, 'F. $d$ ' Ulietca' Jeu d'Or, 1700-1799, France; The Metropolitan Museum of Art 59.654.14(26), Gift of the Estate of James Hazen Hyde, 1959.

The Orpheus figure, unusually garbed in Ottoman dress, appears in eight enigmatic quilts (Illustration 7). According to Greek myth, Orpheus produced beautiful music that transfixed animals, moved boulders, blocked siren song, even outdid the gods of the Underworld. Mosaics in present day Italy, France and Turkey, dating as far back as 170 A.D, show him encircled by bewitched animals. Italian Renaissance humanists also celebrated Orpheus, calling him a "symbol of the power of the word to soften the wild hearts of man and bring civilization." 40 Beset by threats to his authority, Duke Cosimo I de' Medici of Florence, commissioned Agnolo Bronzino to paint him as a new Orpheus, able to subdue political crosscurrents. Gabrielle Langdon writes, "Cosimo-Orpheus's role as poet, lover, pacifier, connoisseur, scholar, and musician casts him in heroic triumph over Cerberus.... and may well promote him as savior of Florence." ${ }^{41}$ European artists continued to represent Orpheus through the following centuries, his role as civil conciliator firmly in his repertoire.

\footnotetext{
${ }^{39}$ Kynan-Wilson, "The Origins of Orientalism," 34-35.

40 John Warden, ed., Orpheus: metamorphosis of a myth, xii. Philadelphia Museum of Art inv\# 1950-86-1; philamuseum.org/collections/permanent/52029.html.

${ }^{41}$ http://www.caareviews.org/reviews/782\#.YA87LJNKh_8.
} 

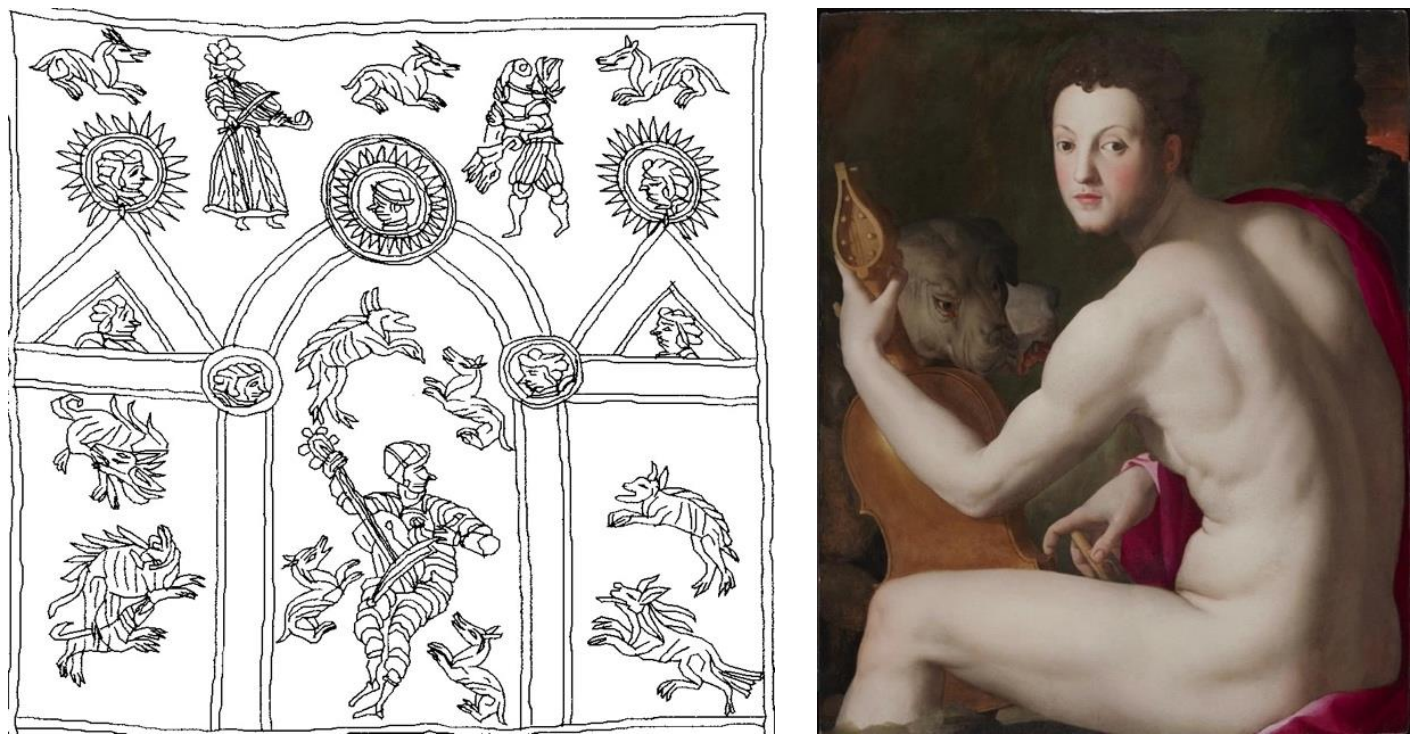

Illustration 7: At left, Orpheus plays to birds and beasts, top panel of International Quilt Museum, 2009.014.0003, Lincoln NE; drawing (C) Linda Baumgarten. At right: Portrait of Cosimo I de' Medici as Orpheus, Agnolo Bronzino, 1537, Philadelphia Museum of Art, inv. 1950-86-1 Gift of Mrs. John Wintersteen, 1950.

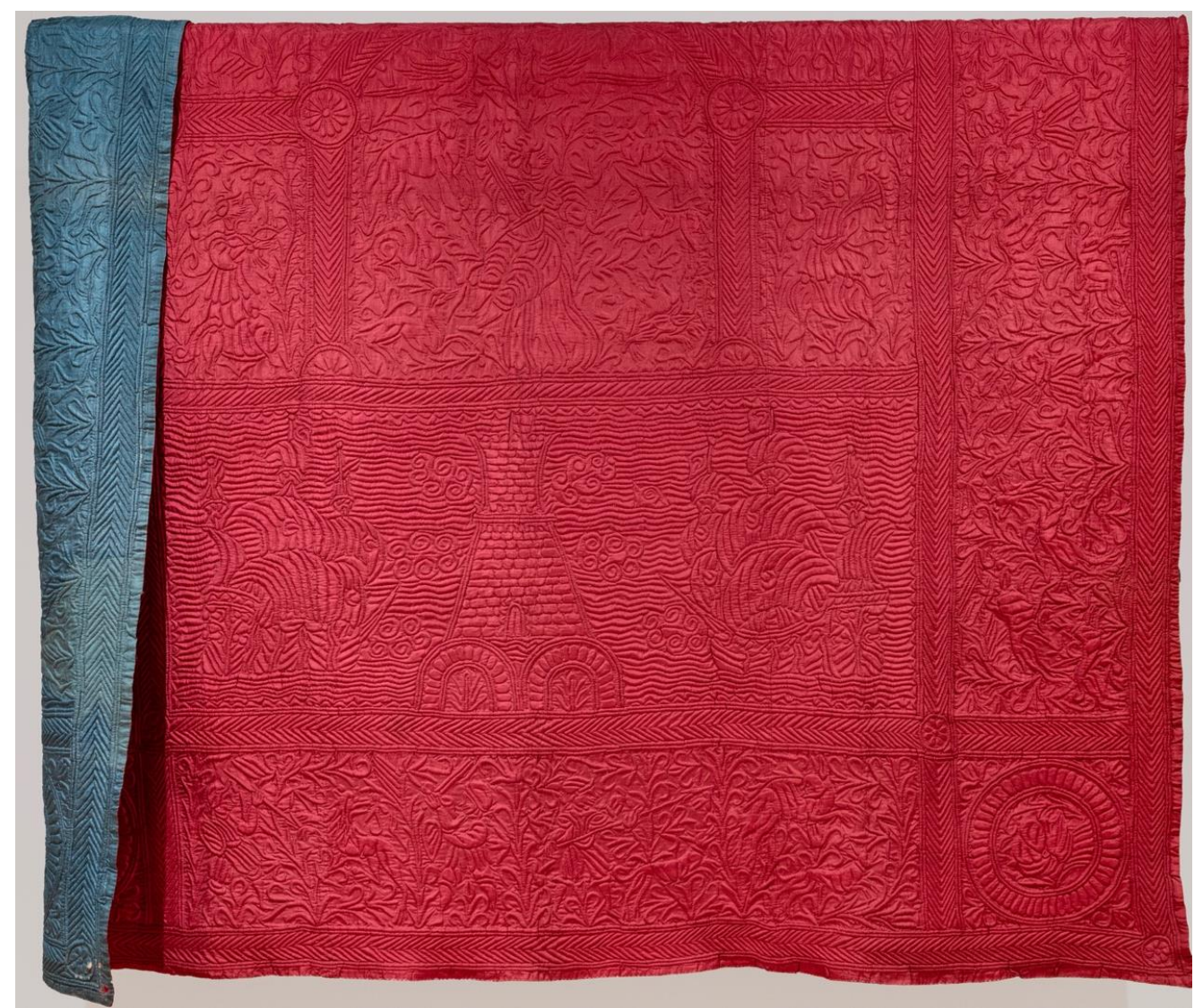

Illustration 8: In this quilt, the scene above the border shows two Ottoman galleons, identified by crescents on their sails, firing cannons on a fortress. Notice the ships are almost mirror images of each other. Wadsworth Atheneum Museum of Art, Hartford, CT, Whole Cloth Quilt 1977.71; South European, seventeenth century. Purchased through the gift of Henry and Walter Keney. Photo: Allen Phillips $\backslash$ Wadsworth Atheneum. 
Of all of these motifs, the ship reasonably might be called the main character and is the only one represented in identical form. Eight quilts depict the exact same galleon from the exact same angle; there must have been one master drawing. ${ }^{42}$ These scenes of armed ships speak to pride in naval prowess at a time of large-scale international trade and concomitant need to well protect goods and ports (Illustration 8). They also help set a date range for the quilts. The V\&A sent photos of the Angelini quilt to National Maritime Museum (NMM) experts in Greenwich, UK, asking for vessel identification. The reply was specific, "The ships are Mediterranean galleys of the mid-sixteenth century: it is most unlikely that vessels of this type would have been reproduced after the year 1600. ${ }^{43}$ But in 2019, Robert Blyth, curator of World and Maritime History at the NMM, extended the date range to 1700; he added that this model of galleon, with a large hold and able to bear cannons, was so efficient that all major navies adopted it. ${ }^{44}$ To avoid confusion, flags and sail markings identified who was friend and who was foe. Tellingly, four of the silk quilts show scenes of ships marked with Ottoman crescents near the crowned doubleheaded eagle emblem commonly associated with the Habsburg Empire The relationship casts both empires in a positive light, an inconsistent pairing for two forces that were at war for most of the sixteenth and seventeenth centuries.

The crowned double-headed eagle motif appears in a majority of the enigmatic quilts (Illustration 9). In the 1200s, peoples from Syria (then ruled by the Mamluks) to Cornwall
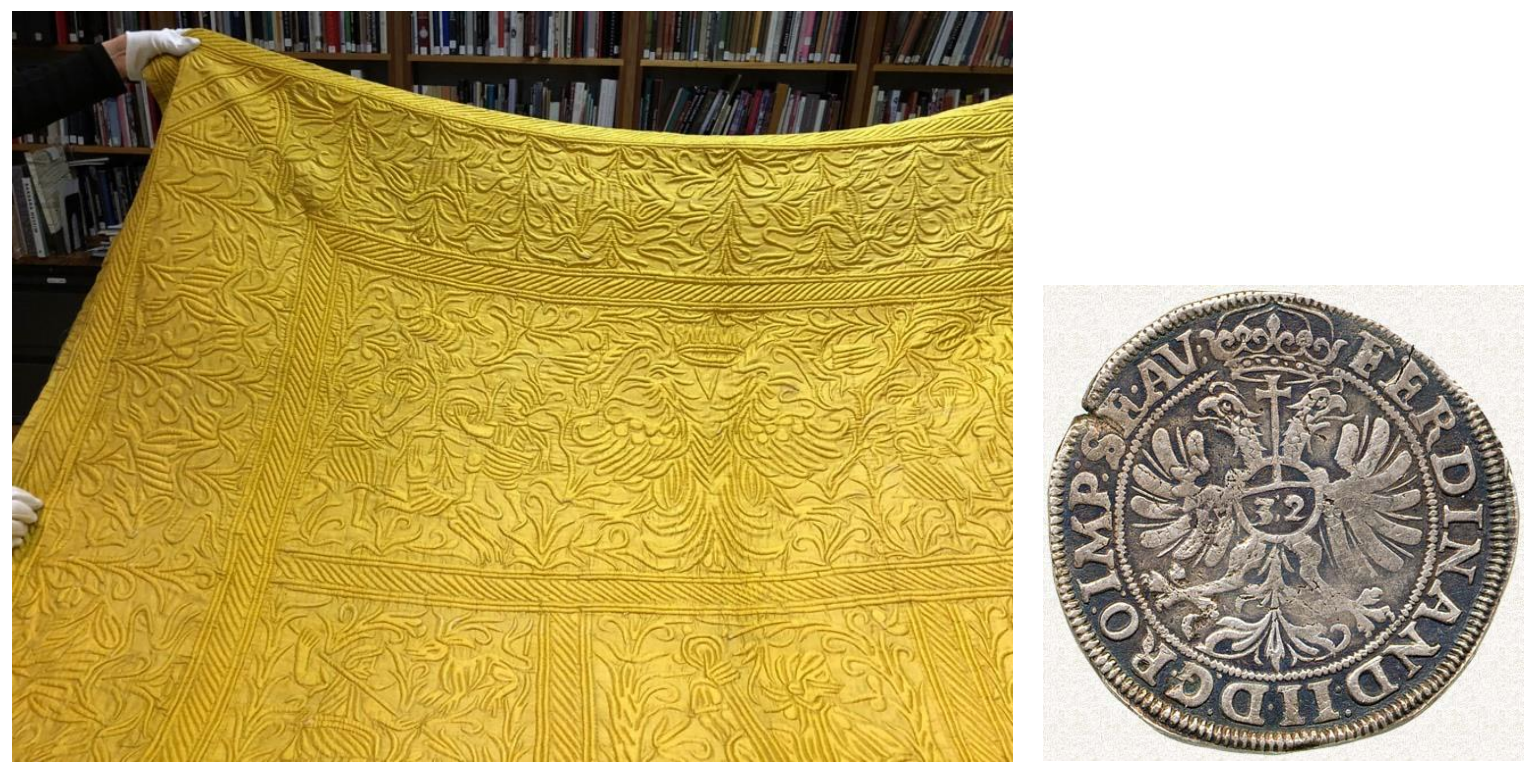

Illustration 9: At left, a crowned double-headed eagle in the top border of the Quilted Bed Cover in the Museum of Fine Arts, Boston inv. 43.817. Photo by author. At right, coinage of Ferdinand II, Holy Roman Emperor, showing the Habsburg coat of arms, 1622, Dept of Medals and Coins, (C) Fitzwilliam Museum, University of Cambridge.

\footnotetext{
${ }^{42}$ Artisans from east to west used pounces -- stencils with small perforations along pattern lines, through which graphite powder could be blown to mark the textile beneath.

${ }^{43}$ A.P. McGowan, letter to D. King, August 17, 1967.

${ }^{44}$ Robert Blyth, personal interview by author, October 16, 2019.
} 
adopted two-headed eagle emblems. ${ }^{45}$ The Byzantines claimed the crowned double-headed eagle as a symbol of Christianity. By the 1600s, an even more ornamented crowned two-headed eagle represented members of the Holy Roman Empire, particularly the Habsburg Princedoms, including Spain and Austria, realms antagonistic toward the Ottomans and not in good stead with Britain during the sixteenth and seventeenth centuries. ${ }^{46}$ (The crowned double-headed eagle stitched in the top tier of the Wharncliff quilt probably led V\&A curators to first link it to past Habsburg rule of Germany.)

The similarities among the motifs stitched within the enigmatic quilts is limited and repetitive: the galleons exact copies, the imagery of Orpheus dressed in Eastern clothing, female figures and crowned double-headed eagles all comparable if not identical. Evidently, the quilt workshops functioned in a coordinated fashion, within a relatively short period of time.

Europe and the Ottomans: A brief history of international conflicts and alliances sheds light on the contemporary references within the quilt motifs. In 1453 Ottomans seized Constantinople (now Istanbul) from European control. They overthrew the Mamluks of Egypt in 1517 and eventually created a powerful empire that circled from Budapest to Bagdad, down the Mediterranean coast to Mecca, then west across Africa to Algiers - larger than any alliance of European countries. Rulers of Roman Catholic countries, such as Habsburg Spain and the Habsburg Principalities, who considered themselves defenders of Christendom, were aghast; their subsequent interactions with the Muslim Ottomans were unfailingly hostile. At the same time, Protestant Britain was at odds, if not at war, with Spanish and the Austrian Habsburgs over continental power struggles. Britons chose to profit from association with the Muslim "superpower." Queen Elizabeth I and Sultan Murad III signed a pact in 1580 that launched two centuries of mutual economic favor.

In 1714, through a quirk of irony related to earlier British civil wars, George I, a Habsburg, succeeded to the British throne. This German King of England, who did not speak English, set his sights on negotiating an end to the Austro-Turkish war -- as if he were Orpheus calming those two beasts of Europe. The ambassador George I named to the Turkish Ottoman court was none other than Edward Wortley Montagu, great-grandfather of the Earl of Wharncliff who gave the indigo quilt to the V\&A in 1886. Wortley Montagu, accompanied by his wife, Lady Mary, began negotiations in Vienna at the court of Emperor Charles VI of Austria, then on to Adrianople where Ottoman Sultan Ahmed III held court. The couple returned to London in 1718, just when the Austrians and Turks signed the Treaty of Passarowitz, ending the long period of rancor between their nations. ${ }^{47}$ Indeed, George I of England had subdued the political cross currents.

${ }^{45}$ Incense burner, Damascus, Syria, c1278, with two-headed eagle emblem of a Mamluk amir, British Museum 1878,1230.682; floor tile with two-headed eagle of Richard, Earl of Cornwall, Dorset, 1270-1300 V\&A Museum 1310-1892.

46 The Habsburg crowned double-headed eagle emblem even appeared in Chinese embroideries made for the Portuguese market; see Maria João Pacheco Ferreira, "Chinese Textiles for Portuguese Tastes," 51.

${ }^{47}$ Wortley Montagu conducted most of the mediations but was replaced just before the treaty was signed. Lady Mary's prolific letters to members of the British court and literati hold detailed accounts of her experiences: rapport with nobility in Habsburg and Ottoman courts, lessons in Turkish language and culture, forays (always in veiled Muslim dress) to mosques, harems and women's bath houses; see Montagu, The Turkish Embassy Letters. 
Conclusion: The previous discussion tends to support the opening proposal of this paper: that workshops produced the enigmatic quilts later than other textile historians have offered. I agree that the works probably originated in the Mediterranean or Aegean basin, with a partiality toward workshops located near Tripoli, Syria, or near the city of Naples, Italy, based on numerous inventory references to them.

Previous studies have appropriately relied on interpretation of the quilts' motifs to set an appropriate date range for their making. This paper does as well, in the context of the historical record of conflicts and resolution. Rational historians have linked quilt images to those produced by European artists in the 1500s. To reconcile a later date for making the quilts, it is enough to say that artists frequently copy from the past. ${ }^{48}$ The anomalies in the quilt images provoke a thoughtful appraisal of their meaning.

The fraught relations between the Habsburg and Ottoman Empires began in the 1540s. Periodic attempts at détente never achieved a level of success equal to the 1718 accord. This unprecedented conciliation of these two warring empires is visually acknowledged by imagery that shows their peoples in comity; European and Ottoman men hunt and play together. Ottoman nobles appear on either side of the heraldic emblem at the top of the V\&A quilt and other quilts show the same heraldry near ships that display Ottoman crescents. Such juxtapositions are appropriate only when the parties' interests coincide (Illustration 10).
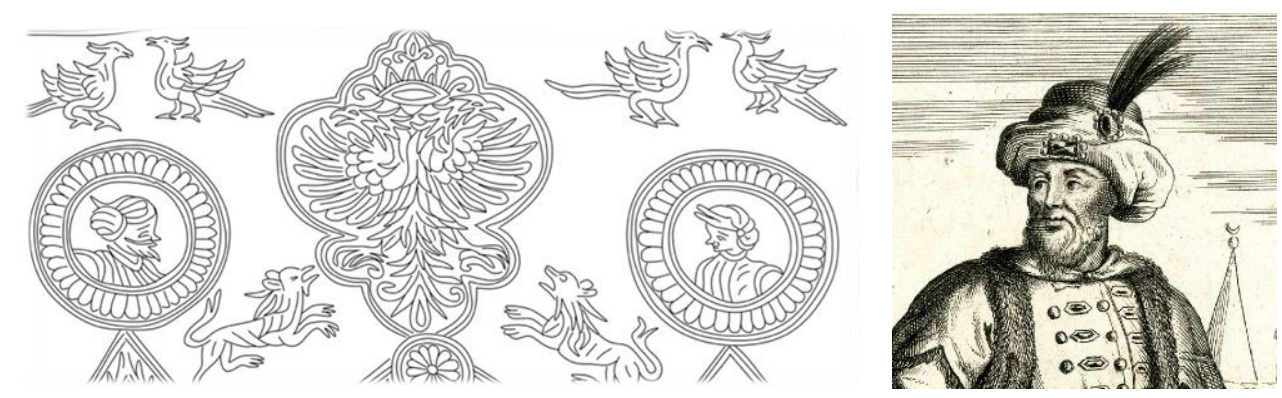

At left: Portrait roundels at the top of V\&A quilt 349-1886 conceivably depict the men who negotiated the Passarowitz Treaty of 1718. The man in the left roundel looks much like Celebi Mehemet Effendi, who signed the treaty on behalf of Sultan Ahmed III. Drawing ( $\odot$ Linda Baumgarten; At right, an engraving of Celebi Mehemet Effendi dated 1721, when he served as the Ottoman ambassador to France. British Museum \# 1871,0812.4681 (C) Trustees of the British Museum.

I suggest the quilts were made soon after the Treaty of Passarowitz and its accompanying commercial agreement were signed. The Ottoman Empire lost territories east of the Danube to Austria but gained mutually beneficial commercial exchange with the Habsburgs. Britain regained its profitable trade with the eastern Mediterranean that had been disrupted by war.

It is reasonable to propose that a celebration of successful arbitration by the British that effected an end to centuries of hostilities would be the moment to throw Habsburg eagles and Ottoman crescents together with Orpheus, renowned soother of discord. ${ }^{49}$ King George I confirms

\footnotetext{
${ }^{48}$ Linda Baumgarten raises this possibility in “The Designs on a Group of Reversible Silk Quilts,” 9; http://www.lindabaumgarten.com/Research.html.

${ }^{49}$ British appreciation for the Orpheus myth continued through the 1700s. In 1721 Lady Mary Wortley Montague evoked Orpheus in her poem "Impromptu to a Young Lady Singing": The power of Orpheus lives in you/
} 
solidarity with his royal Austrian cousins. George Augustus, duke of Cornwall, now that ships can enjoy safer passage on the seas, is assured of income from tin sales to the Ottomans, their former primary customer. Those in SW England's tin business equally benefit; and perhaps that is why five enigmatic quilts came from area families. That Edward Wortley Montagu's greatgrandson possessed one of these wonderful pieces appears to be less of a coincidence.

The many Habsburg crowned double-headed eagle emblems intimate that a Habsburg or Habsburg sympathizer ordered the making of the quilts in this study. If so, how convenient that Austrian Habsburg rule of the Kingdom of Naples/Sicily began in $1714 .{ }^{50}$

Appendix 1: Museum websites for additional images and catalog listings; when necessary, enter item inventory reference in the site's Search Bar.

Art Institute of Chicago, artic.edu

Colonial Williamsburg Foundation, emuseum.history.org/search/*

International Quilt Museum, Lincoln NE, https://www.internationalquiltmuseum.org/collections click on Search)

Isabella Stewart Gardner Museum, https://www.gardnermuseum.org/experience/collection

Los Angeles County Museum of Art, https://collections.lacma.org/node/170403

Museum of Fine Arts, Boston, https://collections.mfa.org/search/objects/*/43.817

Royal Ontario Museum 975.349 https://collections.rom.on.ca/objects/364037.

Victoria \& Albert Museum, collections.vam.ac.uk

Wadsworth Atheneum Museum of Art, https://www.thewadsworth.org/collection/

Winterthur Museum, http://www.winterthur.org/collections/online-collections/ click on Museum Collection Digital

DataBase.

\section{Bibliography}

Argenti, Philip P. The Occupation of Chios by the Genoese and their Administration of the Island, 1346-1566. Cambridge: Cambridge University Press, 1958.

Ballian, Anna. "From Genoa to Constantinople: The Silk Industry of Chios." In The Mercantile Effect. Art and Exchange in the Islamicate World during 17th-18th Centuries, edited by Sussan Babaie and Melanie Gibson, 86-101. London: Gingko Library, 2017.

Baumgarten, Linda and Kimberly Smith Ivey. "Silk Corded." In Four Centuries of Quilts, The Colonial Williamsburg Collection, 21-28. Williamsburg and New Haven: Colonial Williamsburg Foundation and Yale University Press, 2014.

Berenson, Kathryn. "Italian Bedfellows: Tristan, Solomon \& 'Bestes," (2018). Textile Society of America Symposium Proceedings. 1064; https://digitalcommons.unl.edu/tsaconf/1064.

Bresc-Butler, Geneviéve, and Henri Bresc. Une maison de mots: Inventaires de boutiques, d'ateliers et de châteaux de Sicile XIII-XV siècles, I-VI. Palermo: Associazione Mediterranea, 2014.

Bruchet, Max. "Trois inventaires du Château d'Annecy." In Mémoires et documents publiés par la Société Savoisienne d'histoire et d'archéologie. XXXVIII, $2^{\mathrm{e}}$ série, 316-41. Chambéry, 1899.

Deville, Achille. Comptes de dépenses de la construction du château de Gaillon. Paris, 1850.

The raging passions of my soul subdue/ And tame the lions and the tigers there; see Robert Halsband, The Life of Lady Mary Wortley Montagu, (New York, Oxford University Press, 1957) 106.

${ }^{50}$ A privilege achieved at the end of the War of Spanish Succession. 
Doe, Helen "Cornish Ports in the Eighteenth Century." In Payton, Philip. Alston Kennerley and Helen Doe, eds., The Maritime History of Cornwall, 182-195. Exeter: University of Exeter Press, 2014.

Eaton, Linda. Quilts in a Material World: Selections from the Winterthur Collection. New York: Abrams, 2007.

Gay, Victor and Henri Stein, Glossaire Archéologique du moyen age et de la Renaissance. Paris, 1887.

Gerrard, Sandy. The Early British Tin Industry. Stroud: Tempus Publishing, 2000.

Halsband, Robert. The Life of Lady Mary Wortley Montagu. New York: Oxford University Press, 1957.

Hatcher, John. English Tin Production and Trade Before 1550. London: Oxford University Press, 1973.

Havard, Henry. Dictionnaire de l'ameublement et de la décoration depuis le XIII siècle [...], I. Paris, 1887.

Kynan-Wilson, William. "The Origins of Orientalism: A Plurality of Orients and Occidents, c. 1500-1800." In William Greenwood and Lucien de Guise, eds., Inspired by the East: how the Islamic world influenced Western art, 30-41. London: British Museum Press, 2019.

Labarte, Jules, ed., Inventaire du mobilier de Charles V, roi de France. Paris, 1879; gallica.bnf.fr/ark:/12148/bpt6k114570g.

Lidz, Margaret Renner. "The Mystery of Seventeenth-Century Quilts.” The Magazine Antiques December 1998, 834-843.

Mauceri, Enrico. "Inventari inediti dei secoli XV e XVL," In Archivio Storico per la Sicilia Orientale, 105-117. Catania: Società di Storia Patria per la Sicilia Orientale, 1915.

Mazzaoui, Maureen Fennell. The Italian Cotton Industry in the Later Middle Ages, 1100-1600. Cambridge: Cambridge University Press, 1981.

Montagu, Mary Wortley, Teresa Heffernan and Daniel O'Quinn. The Turkish Embassy Letters. Teresa Heffernan and Daniel O’Quinn, eds. Peterborough CA: Broadview Editions, 2013.

Pacheco Ferreira, Maria João. "Chinese textiles for Portuguese tastes." In Amelia Peck, ed., Interwoven Globe: The Worldwide Textile Trade, 1500-1800, 46-55. London: Thames \& Hudson, 2013.

Payton, Philip. Alston Kennerley and Helen Doe, eds., The Maritime History of Cornwall. Exeter: University of Exeter Press, 2014.

-------. "Maritime history and the emigration trade: the case of mid-nineteenth-century Cornwall," in History in Focus: The Sea, Issue 9, non-paginated; at https://archives.history.ac.uk/history-in-focus/Sea/articles/payton.html.

Phillips, Amanda. Everyday Luxuries: Art and Objects in Ottoman Constantinople, 1600-1800. Dortmund: Verlag Kettler, 2016.

Warden, John, ed., Orpheus: The Metamorphosis of a Myth, Toronto: University of Toronto Press, 1982.

Whetter, James. Cornwall in the Seventeenth Century. Padstow UK: Lodenek Press, 1974.

Acknowledgments: I thank Linda Baumgarten for her invaluable contributions to this paper, including her clear, invaluable drawings. I also thank the museum curators who readily shared their expertise and went out of their way to assist once the pandemic closed off the opportunity to see all of these quilts in person. 